\title{
THE PREVALENCE OF PNEUMOCONIOSIS AND TUBERCULOSIS AMONG EARTHENWARE TOWERS
}

\author{
BY \\ E. POSNER \\ From the Stoke-on-Trent Mass Radiography Centre \\ (RECEIVED FOR PUBLICATION AUGUST 23, 1955)
}

In the manufacture of general earthenware in Great Britain, towing means the process of smoothing the edges and surfaces of plates, dishes, saucers, etc., in the unfired "green" stage. The articles are placed on rapidly rotating, power-driven wheels provided with hoods and local dust extraction of various designs. The edges are smoothed with tow and pieces of flannel (Fig. 1). In the American ceramic industry and in the tile section of the north Staffordshire pottery industry the process is called "fettling" or "finishing", and in both countries the work is done almost entirely by women.

The dust arising from the process is that of the unglazed, unfired, brittle earthenware-body, the composition (Rosenthal, 1949) of which is approximately as follows :-

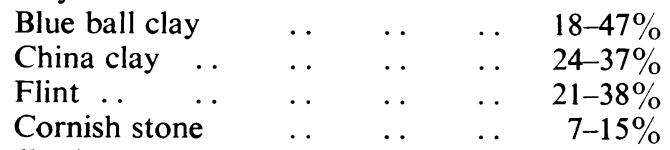

Ball clays consist mainly of kaolinites $\left(\mathrm{Al}_{2} \mathrm{O}_{3}\right.$, $2 \mathrm{SiO}_{2} .2 \mathrm{H}_{2} \mathrm{O}$ ), a decomposition product of felspar. They contain some fine grained quartz and iron and lime impurities.

China clays are mineral kaolinites with only few impurities. Flint, as used in English earthenware, is cryptocrystalline free silica containing about $1 \%$ of water and a small amount of organic matter. It is broken up by calcining, milled into a fine powder, and mixed with the other parts of the earthenware body. Cornish stone consists mostly of coarsely crystalline felspar and quartz quarried in rock form and finely ground before use (Keeling, 1953).

Although towing has for long been known amongst potters as a very dusty occupation, little information about the prevalence of chest diseases, particularly pneumoconiosis, has so far been published. This lack of statistical information seems to be due to the exclusion of female earthenware workers from the periodical examinations under the Medical Arrangements Schemes of 1931 and 1939 and the similar provisions under the Industrial Injuries Act. In the earthenware industry comprehensive analyses based on periodical examinations exist only for men (Meiklejohn, 1947, 1949a).

In his classical account of dust diseases in the north Staffordshire pottery industry, Arlidge (1892) mentions " the particularly unhealthy conditions" in towers' shops. At that time $x$-ray evidence of pneumoconiosis in the pottery industry was, of course, not available.

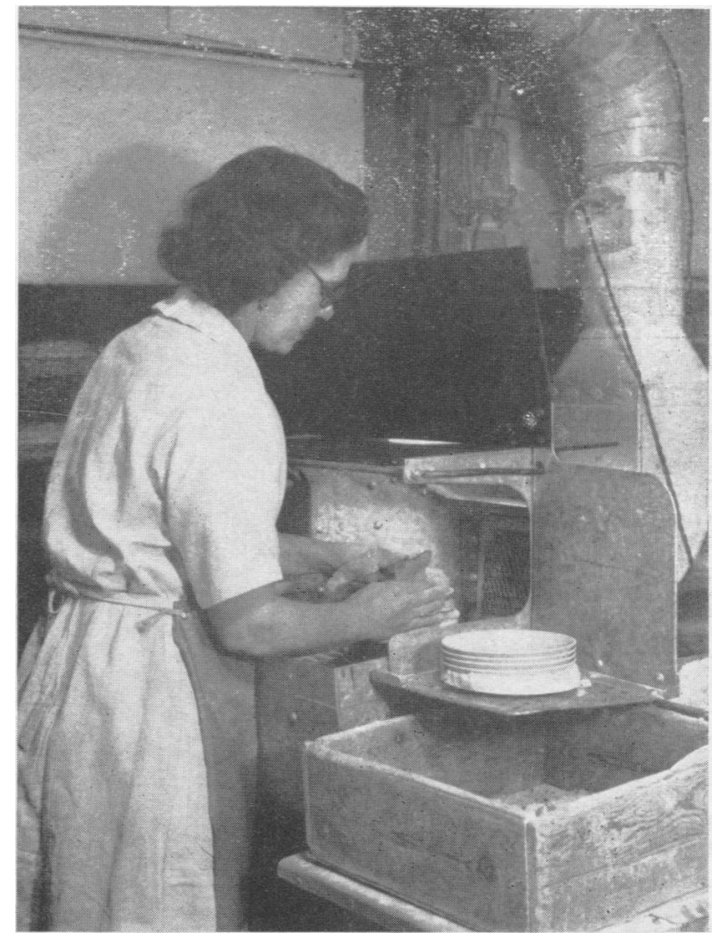

FIG. 1.-Earthenware tower working with an experimental model of a new towing hood designed by the British Ceramic Research Association. 
Sutherland and Bryson (1926) first showed the seriousness of dust disease in the pottery industry by a planned investigation using radiography. The enquiry included 17 towers, one of whom showed radiological signs of silicosis and three evidence of fibrosis, which, it may be assumed, would today be recognized as cases of simple pneumoconiosis of the mixed dust type.

After the introduction of workmen's compensation for scheduled workers in the pottery industry Middleton (1936) analysed the deaths due to silicosis in pottery workers between the years 1930 and 1934. of nine female operatives, in whom death was considered at necropsy to be due to silicosis, three were towers. This appears to be a high ratio, as only about $10 \%$ of all women employed in the clay departments of the earthenware industry are towers.

In the United States, where ceramics, similar in composition to English earthenware, are produced, in Virginia, Flinn, Dreesen, Edwards, Riley, Bloomfield, Sayers, Cadden, and Rothman (1939) found high morbidity rates for silicosis in a group of 83 fettlers. In a larger series Noe (1953) found 25 cases of nodular fibrosis in 214 fettlers and finishers.

Preliminary mention was made in a recent publication (Posner, 1954) of some of the results of examining towers in north Staffordshire. The results are based on mass miniature radiography. As the validity of this method is often considered to be doubtful, the response to these surveys in the pottery industry and the method of the investigations must be described in some detail.

\section{The Response of Volunteers}

The 457 earthenware towers in this series attended at 119 factory surveys. Because employment data were not everywhere available, it was not possible to compare this figure with the total number of towers employed at the same time in Stoke-on-Trent, but in $\mathbf{3 3}$ factories, chosen at random, the number of towers on the pay roll was 268, of whom 192 attended.

This response of $72.4 \%$ is almost the same as that by all women operatives in the north Staffordshire pottery industry, of whom 25,458 out of 34,834 attended mass miniature radiography surveys (73.1\%). Elsewhere I have shown (Posner, 1954) that the lapse rates by middle-aged and elderly women in the dust and clay departments of the industry were significantly lower than those in the decorating departments of the same factories. Since pneumoconiosis in occupations in potteries rarely becomes radiologically manifest before the age of 35 years (approximately 20 years of occupa- tional risk), this relatively good response by higher age groups is of great importance. From a comparison with a wage census in 1954, which gives the number of towers over the age of 21 as 445 , it is estimated that the response by towers over the age of 35 was in fact nearer $80 \%$ than $70 \%$. The sample, therefore, exceeds considerably the number examined by Sutherland and Bryson and by the American authors.

\section{Industrial Histories}

The taking of comprehensive industrial histories is frequently neglected at mass miniature radiography routine surveys (Cochrane, 1951). This has been avoided at Stoke-on-Trent surveys, where the emphasis at factory sessions was entirely shifted from clinical to occupational data and all booking-in clerks were well trained in the procedure.

\section{The Use of 35-mm. Film}

There has been increasing evidence that the reading of radiographs by a single observer, particularly with regard to pneumoconiosis, is liable to considerable errors and variation of interpretation (Fletcher and Oldham, 1949 ; Cochrane, 1951) and these errors and variations increase with diminishing film size (Fletcher, 1952; Newell and McCallum, 1954). It is, therefore, necessary to emphasize that the present results originate from routine mass miniature radiography surveys and not from a research project to investigate the prevalence of pneumoconiosis in towers. At the time of the surveys (1952-54) dual independent reading of miniature films had not yet been introduced into routine mass radiography in this country, but intra-individual dual reading of all rolls of films, which contained radiographs of towers together with a larger number of films of other female clay workers, was arranged.

As a result, 115 towers, or $25.1 \%$ of the total, were recalled for full-sized films. The proportion of recalled female plate-makers and casters in the same age groups was very similar. With the exception of seven persons, all recalled towers were over the age of 35.

Despite this high rate of recall, it is highly probable that some cases of early simple pneumoconiosis were missed on the miniature films and that the absolute prevalence rates, shown in Tables 1 and 2 for each group, err by understatement. I would, therefore, suggest that this and similar investigations should be considered no more than a general guide to the relative prevalence in the many and varied occupations, each involving a varying degree of risk from dust in certain industries. Of such industries, pottery manufacture, an industry of many skilled artisans with a large number of 
different occupational risks, is an example par excellence. As comprehensive examinations using large film of female earthenware operatives have been absent in the past and are not likely to be introduced in the near future, this guide to relative prevalences and risks amongst these women is important.

\section{The Reading of Full-sized Films}

In all 60 cases shown in Table 1 at least two out of three observers agreed in a diagnosis of pneumoconiosis or pneumoconiosis accompanied by tuberculosis. I suspected originally the presence of pneumoconiosis in 73 patients, who were advised to make a claim to the Pneumoconiosis Board. Only 65 did so, of whom $54(83 \%)$ were certified by the Board. The films and industrial histories of those women who failed to submit a claim (eight cases) and of those who were not certified by the Board (11 cases) were sent to Dr. Meiklejohn for his opinion. He expressed a positive opinion on the radiological presence of pneumoconiosis in six of these patients, five of whom had not attended the Pneumoconiosis Board. These six cases, agreed by two observers, were added to the 54 certified cases, giving the total of 60 . Three films of poor quality, which could not be repeated, were excluded from further analysis.

\section{The Classification of Full-sized Films}

Pathological investigations by Gloyne (1951) in English and by Kirch (1953) in Bavarian potters have shown that the type of mixed dust pneumoconiosis is common in both. The Bavarian porcelain workers handle similar material to English potters (Schneider, 1955, personal communication). It is, therefore, not surprising that many radiographs of English earthenware workers do not present the typical appearances of classical silicosis but a great variety of minute (less than $5 \mathrm{~mm}$.), unevenly distributed, irregularly shaped, fluffy or angular and strandy shadows. An accurate classification of these films according to the scheme of the I.L.O. conference in Sydney (Cochrane, Davies, and Fletcher, 1951) presents considerable difficulties and in this analysis no further subdivision into categories of simple pneumoconiosis has been attempted.

The radiographs of potters with progressive massive fibrosis present the same difficulties of differential diagnosis between that condition and active pulmonary tuberculosis as those of coalminers (Cochrane, Cox, and Jarman, 1952). It is worth while recalling that Gloyne (1951) found pathological evidence of tuberculosis in $43 \%$ of potters' lungs, and that Meiklejohn (1949b) has said " tuberculosis may become manifest, even when the degree of s:'icosis is minimal ".

For the present analysis only those cases of tuberculosis were accepted as active which the area chest physicians graded and notified A or B, I, II, III, according to the classification of the Ministry of Health. The criteria for the inclusion in these groups were sputum tests and the usual clinical signs, such as loss of weight and raised sedimentation rates. The same chest physicians assessed the cases during the whole period of the investigation and it is unlikely that their standard of assessment altered during that time.

\section{Prevalence of Pneumoconiosis}

The radiological prevalence of pneumoconiosis amongst earthenware towers according to periods of occupational risk is shown in Table $\mathrm{I}$. There are

TABLE 1

PREVALENCE OF RADIOLOGICALLY MANIFEST PNEUMOCONIOSIS IN 457 EARTHENWARE TOWERS ACCORDING TO PERIOD OF OCCUPATIONAL RISK

\begin{tabular}{|c|c|c|c|c|c|c|}
\hline $\begin{array}{c}\text { Period of Employment } \\
\text { in Years }\end{array}$ & $\begin{array}{c}\text { Less } \\
\text { than } \\
10\end{array}$ & $10-19$ & $20-29$ & $30-39$ & $\begin{array}{c}40 \\
\text { and } \\
\text { over }\end{array}$ & Total \\
\hline $\begin{array}{l}\text { Number } x \text {-rayed } \\
\text { Simple pneumoconiosis }\end{array}$ & 98 & $\begin{array}{r}93 \\
2\end{array}$ & $\begin{array}{r}111 \\
13\end{array}$ & $\begin{array}{r}118 \\
17\end{array}$ & $\begin{array}{l}37 \\
10\end{array}$ & $\begin{array}{r}457 \\
42\end{array}$ \\
\hline $\begin{array}{cc}\text { Progressive } & \text { massive } \\
\text { fibrosis } & \ldots\end{array}$ & - & 1 & 6 & 5 & 2 & 14 \\
\hline $\begin{array}{l}\text { Silicosis accompanied } \\
\text { by tuberculosis } \\
\text { Total pneumoconiosis } \ldots \\
\text { Morbidity rate }(\%) \quad \ldots\end{array}$ & E & $\begin{array}{l}-3 \\
3 \cdot 2\end{array}$ & $\begin{array}{l}\overline{19} \\
17 \cdot 1\end{array}$ & $\begin{array}{l}4 \\
26 \\
22 \cdot 0\end{array}$ & $\begin{array}{l}\overline{12} \\
32 \cdot 4\end{array}$ & $\begin{array}{l}4 \\
60 \\
13 \cdot 1\end{array}$ \\
\hline
\end{tabular}

no cases with an employment history of less than 10 years. Between 10 and 19 years the prevalence rate is still low (3.2\%) but it rises steeply afterwards to over $30 \%$ in women with more than 40 years' exposure.

In Table 2 the prevalences of all stages of radiologically manifest pneumoconiosis in towers with more than 20 years' employment are compared with those of other female earthenware workers, who were examined in the same factories and under the same conditions as the towers. The rates for towers are strikingly higher.

TABLE 2

PREVALENCE OF RADIOLOGICALLY MANIFEST PNEUMOCONIOSIS IN SOME GROUPS OF FEMALE EARTHENWARE WORKERS WITH OCCUPATIONAL HISTORY OF MORE THAN 20 YEARS

\begin{tabular}{|c|c|c|c|}
\hline Group & $\begin{array}{c}\text { No. Radio- } \\
\text { graphed }\end{array}$ & $\begin{array}{l}\text { Pneumo- } \\
\text { coniosis }\end{array}$ & $\begin{array}{c}\text { Morbidity } \\
\text { Rate } \\
(\%)\end{array}$ \\
\hline $\begin{array}{l}\text { Plate and saucer makers includ- } \\
\text { ing assistants . } \\
\text { Cup handlers and spongers } \ldots \\
\text { Custers and casters' spongers.. } \\
\text { Towers } \ldots \\
\text { Towers a }\end{array}$ & $\begin{array}{l}468 \\
401 \\
602 \\
266\end{array}$ & $\begin{array}{l}50 \\
18 \\
45 \\
57\end{array}$ & $\begin{array}{r}10 \cdot 7 \\
4 \cdot 5 \\
7 \cdot 4 \\
21 \cdot 4\end{array}$ \\
\hline
\end{tabular}


Comparison with investigations by other authors (Flinn and others, 1939 ; Noe, 1953) are impossible, as they used a different technique on a differently selected working population. It may, however, be significant that Flinn and others (1939), who found higher rates in 1939, commented on the absence of efficient ventilating systems in American fettlers' shops. In England local dust extraction and the provision of hoods over towers' wheels have existed for many years although, as will be shown later, some of the methods of dust extraction have been far from efficient. The amount of dust breathed by English towers is likely to have been less in the past than that by American fettlers before 1939.

\section{Active and Infectious Pulmonary Tuberculosis}

As the result of the mass radiography surveys, seven towers were notified as suffering from active pulmonary tuberculosis. Three cases (ages 21, 25, and 48) showed no definite radiological evidence of pneumoconiosis and in four cases (ages 51, 53, 55 , and 58) there was a definite pneumoconiotic background. In each group there were two sputumpositive cases ( 21 and 48 years and 48 and 53 years old respectively).

Table 3 shows the rates of active pulmonary tuberculosis in towers compared with those of other earthenware clay workers, biscuit-warehouse workers, dippers, decorators, and finally with women in Stoke-on-Trent who had never been employed in any job in the pottery industry. The criteria for the

\section{TABLE 3}

PREYALENCE OF ACTIVE PULMONARY TUBERCULOSIS IN VARIOUS GROUPS OF WOMEN EARTHENWARE WORKERS AND WOMEN UNCONNECTED WITH POTTERY INDUSTRY OF ALL AGES IN STOKE-ON-TRENT 1952-54

\begin{tabular}{|c|c|c|c|}
\hline Category & $\begin{array}{l}\text { No. Radio- } \\
\text { graphed }\end{array}$ & $\begin{array}{c}\text { Cases of } \\
\text { Active } \\
\text { Tuber- } \\
\text { culosis }\end{array}$ & $\begin{array}{c}\text { Rate per } \\
1,000\end{array}$ \\
\hline 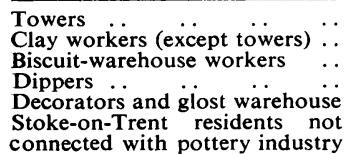 & $\begin{array}{r}457 \\
3,892 \\
940 \\
686 \\
9,271 \\
10,045\end{array}$ & $\begin{aligned} 7(4)^{*} \\
29 \\
5(9) \\
3((-)) \\
24(8) \\
26(9)\end{aligned}$ & $\begin{array}{r}15 \cdot 3 \\
7 \cdot 4 \\
5 \cdot 3 \\
4 \cdot 1 \\
2 \cdot 6\end{array}$ \\
\hline
\end{tabular}

* The figures in brackets are cases with positive sputum. They are included in the total and are not additional.

assessment of activity (see above) were the same for all groups. Although the number of towers and other clay workers, shown in Table 3 , cannot be accurately compared by strict statistical standards, the double rate for towers, compared with other clay workers, is at least strongly suggestive of a true higher prevalence. The differences between towers and earthenware clay workers on the one hand and pottery decorators and women not connected with the pottery industry on the other seem to be statistically highly significant. Pottery decorators share with clay workers the general occupational hazards of factory life, particularly those of crowded workshops, but they are not exposed to a specific risk from dust.

\section{Dust Conditions and Prevention}

The Pottery Health and Welfare Regulations (Ministry of Labour, 1950) consolidated and enlarged the various provisions which had been made in the past by statutory orders (Special Regulations, 1931, 1932, and Factories Act, 1947). Towing is one of the processes scheduled in the 1950 Regulations " which should not be carried out without efficient exhaust draught". In 1951 the British Ceramic Research Association began to investigate dust conditions in towers' shops and at the benches and to test the efficiency of existing designs of hoods and local exhaust ventilation. One of the investigators was W. A. Bloor, who, together with others, had studied dust concentrations in earthenware clay shops before the war but not specifically those related to towers (Bloor, Goodall, and Webb, 1938). The distribution and movement of dust were studied by cinematography with special lighting, which revealed dust clouds invisible under normal conditions. This is a method not only of great technical interest, but also of great demonstrative and educational value to everybody concerned with dust suppression in factories. Quantitative data were obtained by using a thermal precipitator. A number of towing hoods of traditional design were tested, and a new design of hood, developed by the Research Association, was installed in a number of factories and similarly tested. The quantitative data resulting from these investigations are shown in a condensed form in Table 4. All particles shown in Table 4 were of the size 0.5 to 5 microns (Bloor, 1955, personal communication). The reduction of

TABLE 4

DUST CONCENTRATIONS IN TOWERS' SHOPS

\begin{tabular}{|c|c|c|c|}
\hline \multirow[b]{2}{*}{ Hood } & \multicolumn{2}{|c|}{$\begin{array}{l}\text { Particles per c.cm. } \\
(0.5-5 \text { micron })\end{array}$} & \multirow{2}{*}{$\begin{array}{l}\text { Spillage } \\
\text { of Dust } \\
\text { on Floor } \\
\text { (g./hr.) }\end{array}$} \\
\hline & $\begin{array}{l}\text { At } \\
\text { Breathing } \\
\text { Level of } \\
\text { Worker }\end{array}$ & $\begin{array}{c}\text { In } \\
\text { Surrounding } \\
\text { Atmosphere }\end{array}$ & \\
\hline $\begin{array}{cc}\text { Various, old types } & \text { of } \\
\text { towers hoods. } & . .\end{array}$ & $144-310$ & $72-250$ & 15 \\
\hline $\begin{array}{c}\text { New hood designed by } \\
\text { British Ceramic Re- } \\
\text { search Association }\end{array}$ & $28-43$ & $22-40$ & Less than 1 \\
\hline
\end{tabular}

concentration of dust by the new designs and even more of spillage of dust on to the floor is impressive.

The principles of the new hood (Fig. 1), which has now been recognized by H.M. Factory Inspec- 
tors as complying with the existing regulations, are briefly these.

(1) It provides a streamlined airflow into and through the hood.

(2) The towing wheel is so positioned with respect both to the exhaust outlet and the front that the exhaust air is used with maximum efficiency and spilling from the hood is avoided.

(3) The specified minimum horizontal airflow towards the outlet, measured at 2 in. above the centre of the ware, without the air-jet in operation, is $300 \mathrm{ft}$. per min.

(4) A pressure controlled air-jet directed on to the ware safely removes the small amount of loose dust that remains on the surface. This eliminates the necessity for the undesirable practice of " mouth blowing " by the tower.

(5) The side platforms for the accommodation of supplies of ware are so designed as to induce an appreciable airflow over the ware, ensuring that any fine dust produced in this region will be taken into the hood and not dispersed into the general atmosphere of the workroom.

A considerable number of women will remain employed as towers in the north Staffordshire industry and the design of more efficient dust suppression at their working places seems to be an important step forward. At the same time it must not be forgotten that many other measures, such as improved layout of workshops, mechanization, obligatory provision of protective garments, vacuum cleaning of workshops, etc., which have now been widely introduced, should play a most important part in the reduction of pneumoconiosis amongst earthenware towers. The benefits of these improvements can only be assessed after a considerable number of years by periodical $x$-ray examinations of towers, particularly of those who started to work under the much improved hygienic conditions after the last war.

\section{Summary}

Routine mass radiography surveys in Stoke-onTrent revealed high prevalence rates of radiologically manifest pneumoconiosis and of active tuberculosis amongst female earthenware towers.
The limitations of $35 \mathrm{~mm}$. $x$-ray examinations with regard to true prevalence rates and their value with regard to relative prevalence rates in certain industries are discussed.

The principles of newly introduced protective appliances at towers' benches are shown.

I am very grateful to Dr. A. T. Green, O.B.E., Director of the British Ceramic Research Association, for permitting me to use material collected by himself and his staff, and to Messrs. A. Dimsdale and W. A. Bloor who kindly criticized and corrected the technical part of this paper.

Dr. A. Meiklejohn once again let me have the benefit of his great experience with pneumoconiosis amongst potters. Dr. F. A. Smith and Dr. E. Bennion, consultant chest physicians, kindly allowed me free access to their records. I received much helpful advice from Mr. E. Waller, H.M. Factory Inspector at Stoke. The Secretaries of the British Pottery Manufacturers' Federation and of the Hanley Employment Exchange provided useful employment data. Dr. K. W. Cross, Senior Statistical Officer of the Birmingham Regional Hospital Board, very kindly gave his opinion on the significance of tuberculosis rates.

\section{REFERENCES}

Arlidge, J. T. (1892). The Hygiene, Diseases and Mortality of Occupations. Perceval, London.

Bloor, W. A. (1955). Personal communication.

Bloor, W. A. (1955). Personal communication. Soc., 38, 1, 26, and 66 .

Cochrane, A. L. (1951). In The Application of Scientific Methods to Industrial and Service Medicine. (Medical Research Council.) H.M.S.O., London.

-, Cox, J. G., and Jarman, T. F. (1952). Brit. med. J., 2, 843. Davies, I., and Fletcher, C. M. (1951). British Journal of Industrial Medicine, 8, 244.

Fletcher, C. M. (1952). Brux.-méd., 32, 755.

-, and Oldham, P. D. (1949). British Journal of Industrial Medicine, 6, 168 .

Flinn, R. H., Dreesen, W. C., Edwards, T. I., Riley, E. C., Bloomfield, J. J., Sayers, R. R., Cadden, J. F., and Rothman, S. C. (1939). Publ. Hith Bull. (Wash.), No. 244.

Gloyne, S. R. (1951). Lancet, 1,810.

Keeling, P. S. (1953). In A. T. Green and G. H. Stewart Ceramics : A Symposium, p. 1. British Ceramic Society, Stoke-on-Trent.

Kirch, E. (1953). Beitr. SilikoseForsch., Heft 25, p. 1.

Meiklejohn, A. (1947). Trans. Brit. Ceramic Soc., 46, 132.

(1949a). J. industr. Nurses, 1, 24.

(1949b). British Journal of Industrial Medicine, 6, 230.

Middleton, E. L. (1936). Lancet, 2, 1 and 59.

Ministry of Labour (1950). The Pottery (Health and Welfare) Special Regulations, Statutory Instrument 65. H.M.S.O.,
H.Melfare) London.

Newell, D. J., and McCallum, R. I. (1954). J. Fac. Radiol. (Lond.), $6,67$.

Noe, J. T. (1953). Industr. Med. Surg., 22, 255.

Posner, E. (1954). J. industr. Nurses, 6, 183.

Rosenthal, E. (1949). Pottery and Ceramics. Pelican no. 201. Penguin Books, Harmondsworth, Middlesex.

Schneider, H. (1955). Bayerisches Landesinstitut für Arbeitsmedizin. Personal communication.

Sutherland, C. L., and Bryson, S. (1926). Report on the Incidence of Silicosis in the Pottery Industry. H.M.S.O., London. 